\title{
Evaluation of peritoneal reinfection after fecal peritonitis ${ }^{1}$
}

\author{
Avaliação da reinfecção peritoneal após peritonite fecal
}

\begin{abstract}
Luiz Ronaldo Alberti ${ }^{I}$, Andy Petroianu ${ }^{\text {II }}$
IPhD, Associate Professor, Department of Surgery, UFMG, Institute of Research, Postgraduate Program of Santa Casa, Belo Horizonte-MG, Brazil. Technical procedures, acquisition and interpretation of data, statistical analysis and manuscript writing.

IIPhD, Full Professor, Department of Surgery, UFMG, Belo Horizonte-MG, Brazil. Conception, design, intellectual and scientific content of the study, critical analysis, final approval of manuscript.
\end{abstract}

\begin{abstract}
PURPOSE: To investigate the role of a previous abdominal infection on peritonitis.

METHODS: Twenty-seven adult female Wistar rats were submitted to fecal peritonitis by an intraperitoneal injection of a solution of rat feces. The animals were divided into three groups $(n=9$ each): Group 1 - control - intraperitoneal injection of an amount of fecal solution known to be lethal $(10 \mathrm{ml} / \mathrm{kg})$, Group 2 - reinfection - intraperitoneal injection of an amount of fecal solution known not to be lethal $(2 \mathrm{ml} / \mathrm{kg})$ followed by an injection of fecal solution $(10 \mathrm{ml} / \mathrm{kg}) 30$ days later, Group 3 - late reinfection - intraperitoneal injection of $2 \mathrm{ml} / \mathrm{kg}$ feces followed by an injection of $10 \mathrm{ml} / \mathrm{kg}$ four months later.

RESULTS: All animals in Group 1 died within seven days after injection of the fecal solution. In contrast, in the pre-infected Group 2 only one animal died 24 hours after injection of the fecal solution $(10 \mathrm{ml} / \mathrm{kg})$. In Group 3, eight of the nine animals in each subgroup died over a period of seven days. The difference in survival time between groups 1, 2 and 3 was for $p=0.0042$ (logrank test).

CONCLUSIONS: Milder peritoneal sepsis due to fecal infection raises the organic resistance to a new more intense fecal contamination occuring after a short period of time. However, this protection did not persist over a prolonged period of time.
\end{abstract}

Key words: Peritonitis. Sepsis. Infection. Feces. Immunity. Rats.

\section{RESUMO}

OBJETIVO: Investigar o efeito de uma nova infecção peritoneal após realização de peritonite fecal prévia.

MÉTODOS: Foram utilizados 27 ratos fêmea Wistar adultos submetidos à peritonite fecal com injeção intraperitoneal de uma solução de fezes de ratos. Os animais foram distribuidos em três grupos $(n=9)$ : Grupo 1 - controle: injeção intraperitoneal de solução de fezes com uma quantidade sabidamente letal (10 ml/kg); Grupo 2 - reinfecção: injeção intraperitoneal de solução de fezes com uma quantidade sabidamente não letal ( $2 \mathrm{ml} / \mathrm{kg})$ e, após 30 dias, injeção de solução de fezes (10 ml/kg); Grupo 3 - reinfecção tardia: injeção intraperitoneal de fezes a $2 \mathrm{ml} / \mathrm{kg}$ e, após quatro meses, injeção de $10 \mathrm{ml} / \mathrm{kg}$.

RESULTADOS: Todos os animais do Grupo 1 morreram dentro de sete dias após a injeção da solução de fezes. Em contraste, no grupo de reinfecção precoce Grupo 2 apenas um animal morreu 24 horas após a injecção da solução de fezes (10 ml / kg). No Grupo 3, oito dos nove animais morreram durante um período de sete dias. A diferença no tempo de sobrevivência entre os grupos 1,2 e 3 foi de $p=$ 0,0042 (teste de logrank).

CONCLUSÕES: Uma sepse peritoneal menor por fezes eleva a resistência orgânica a nova contaminação fecal mais intensa que ocorra após um período curto. Contudo, essa defesa não persiste por tempo mais prolongado.

Descritores: Peritonite. Sepse. Infecção. Fezes. Imunidade. Ratos. 


\section{Introduction}

Most peritoneal infections are caused by gram-negative and anaerobic bacteria, specially Escherichia coli and Bacteroides fragilis,. Escherichia coli predominates during the acute phase of the process, whereas in the chronic phase, when abscess formation occurs, the predominance is of anaerobic bacteria, mainly Bacteroides fragilis and enterococci, which act synergistically ${ }^{1,2}$.

The association between sepsis and peritonitis has not been fully clarified. During the acute phase, after invasion by gramnegative bacteria, the organism recognizes lipopolysaccharide (LPS) and its major molecule, lipid A, as signals of bacterial penetration. Lipopolysaccharide binding protein (LBP) transfers LPS to CD14 on the surface of monocytes, macrophages and neutrophils ${ }^{3}$. This phenomenon induces the production and release of mediators, such as tumor necrosis factor $\alpha$ (TNF- $\alpha)$ and interleukins 1, 6 and 8, generating the amplification of the LPS signal in plasma and its transmission to other cells and tissues ${ }^{4}$. Associated with these cytokines there is release of phospholipidsderived factors and coagulation factors, complement activation, increased vascular endothelium permeability, and nitric oxide production $^{5}$. It is important to emphasize the occurrence of resistance to peritoneal infection by means of activation of complement factors $\mathrm{C} 3$ and $\mathrm{C} 4$, mast cells, TNF- $\alpha$, and immunoglobulin $\mathrm{M}(\operatorname{IgM})^{6}$.

The first line of defense against a peritoneal infection is natural immunity (neutrophils, macrophages and complement activation, and specific acquired immunity to the invading pathogens by the action of $\operatorname{IgM}^{7}$. The natural immune response is activated immediately after the antigenic stimulus but it lasts for only a short time after the end of this stimulus. However, acquired immunity persists for a longer time. The possible activation of $\mathrm{T}$ cell clones may generates a more prolonged and effective immune defense during subsequent infections. Humoral immunity seems to be the major response that specifically protects against bacteria in its extracellular form ${ }^{8}$.

Few studies are available in the literature about the effects of a new infection after septic peritonitis, and their results are conflicting ${ }^{9,10}$. According to Feterowski et al. ${ }^{9}$ a new aggression during the acute phase of a septic phenomenon generates a better response by the organism as long as it occurs four days after the initial infection. The explanation for this result was that previous exposure to LPS may modulate the defense or the organism by amplifying the natural immunity. Previous exposure may be responsible for the activation and increase in the number of neutrophils by inhibition of apoptosis at the site of infection ${ }^{9}$. In addition, Zhou et al. ${ }^{10}$ observed that exposure to LPS reduced the recruitment of monocytes in the peritoneal cavity by inhibitory regulation of CCR2 receptors on the surface of peripheral blood cells, generating a reduction of the natural immune response.

In a survey of the literature we did not find any report about the results of peritoneal reinfection after longer period of time. The purpose of this study was to provide information about the acquired immunity and possible persistence of the immune defense against this infection

\section{Methods}

This study was performed according to the recommendations of the Guiding Principles in the Care and Use of Animals, and was approved by the Ethics Committee of the Department of Surgery, Medical School, Federal University of Minas Gerais.

Twenty-seven adult female rats, ranging in weight from 2450 to $2700 \mathrm{~g}$, were housed in cages and received rat food and water ad libitum. They were observed for health status during a 10 days-period. The animals were divided at random into three groups $(n=9)$ according to the following protocol:

Group 1 - control: intraperitoneal injection of a quantity of fecal solution known to be lethal $(10 \mathrm{ml} / \mathrm{kg})$, as determined in a pilot study. This solution was introduced on the same day when the second injection of fecal solution was applied to Group 2.

Group 2 - reinfection: initial intraperitoneal injection of a small amount of fecal solution known not to be lethal $(2 \mathrm{ml} / \mathrm{kg})$ as determined in a pilot study. After a 30 day follow-up, a new inoculation of fecal solution $(10 \mathrm{ml} / \mathrm{kg}$ ) was performed, the same injected into group 1.

Group 3 - late reinfection: initial intraperitoneal injection of the fecal solution $(2 \mathrm{ml} / \mathrm{kg})$. After a 4 month follow-up, the same fecal solution $(10 \mathrm{ml} / \mathrm{kg})$ as injected into groups 1 and 2 was inoculated into this group.

The $10 \%$ fecal solution was prepared by placing $2 \mathrm{~g}$ of rat feces in a beaker and adding enough water to complete $20 \mathrm{ml}$. This mixture was homogenized and filtered through gauze to remove fecal particles.

Anesthesia was obtained with an intramuscular injection of $100 \mathrm{mg} / \mathrm{kg}$ ketamine hydrochloride. The fecal solution was injected into the peritoneal cavity with a syringe fitted with a $25 \mathrm{x}$ 7 neddle at the level of the umbilical scar, $0.5 \mathrm{~cm}$ to the left of the abdominal rectus muscle.

All animals had free access to rat chow and water. They were daily monitored and followed during the period determined 
for their group. The rats that died were submitted to autopsy

Data were presented as mean \pm SEM. The weight of the animals of the different groups was assessed one-way ANOVA and the Tukey-Kramer tests. Paired t test compared the initial and final animal weight of the same group. Survival curves of Groups 1, 2 and 3 were plotted using the Kaplan and Meier method and then compared by the log-rank test. $\mathrm{P}$ values $<0.05$ were considered significant.

\section{Results}

The mean of the initial weight of animals of group 1 was $234.8 \pm 12.32 \mathrm{~g}$, of group 2 was $224.9 \pm 8.82 \mathrm{~g}$ and group 3 was $217.54 \pm 7.93 \mathrm{~g}(\mathrm{p}=0.2843)$ demonstrating that the groups were homogeneous and could be compared. Table 1 shows the mean weight of the rats of the three groups in different periods after intrabdominal injection of fecal solution. The absence of difference between the three groups suggests similar caloric intake by the rats of all groups in the different periods.

TABLE 1 - Mean weight \pm standard deviation of mean (g) of the animals of groups 1, 2 and 3 after intrabdominal injection of fecal solution.

\begin{tabular}{ccccc}
\hline \hline & \multicolumn{3}{c}{ PERIOD } \\
GROUPS & Initial & $\mathbf{3 0}$ days & 4 months & $\mathbf{p}$ \\
\cline { 2 - 4 } $\mathbf{1}$ & $234.8 \pm 12.32$ & - & - & - \\
$\mathbf{2}$ & $224.9 \pm 8.82$ & $250.30 \pm 6.90$ & - & $0.0422 *$ \\
$\mathbf{3}$ & $217,54 \pm 7.93$ & $248.12 \pm 5.45$ & $312.25 \pm 11.87$ & $0.0032^{* *}$ \\
$\mathbf{n}$ & $0.2843^{+}$ & $0.359^{++}$ & \\
\hline \hline
\end{tabular}

* Group 2: difference between initial and after 30 days (paired t test)

** Group 3: difference between initial, after 30 days and after four months (ANOVA)

${ }^{+}$: Difference between groups 1, 2 and 3, considering their initial weight (ANOVA)

${ }^{++}$: Difference between groups 2 and 3 after 30 days (paired t test)

All nine animals in group 1 died within a period of seven days after injection of the fecal solution. In contrast, only one animal in group2, which had been pre-infected, died after 24 hours, while the eight other rats remained alive throughout the 30 days of follow-up and showed progressive gain of weight (250.30 $\pm 6.90)(p=0.0422-$ paired $t$ test $)$. The difference in survival time between groups 1 and 2 was for $\mathrm{p}=0.0002$ (logrank test). The survival curves of the Groups 1 and $2(p=0.025)$ were discrepant. Numerically, the estimated hazard ratio for mortality in these two groups was 14.35 (CI: 3.83 - 68.63) (Figure 1).

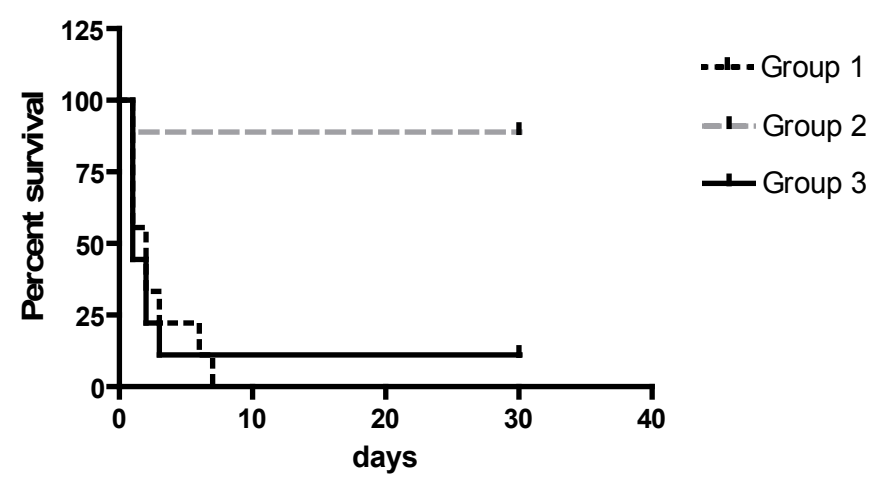

* Difference among the groups 1, 2 and 3 based on the log-rank statistic $(\mathrm{p}=0.0042)$

Difference among the control group and group 2 based on the log-rank statistic $(p=0.0002)$

Difference among the control group and group 3 based on the log-rank statistic $(\mathrm{p}=0.4738)$

FIGURE 1 - Survival curve of the groups 1 - control, group 2 - reinfection after one month and group 3 - reinfection after four months, plotted by the Kaplan and Meier method.

At autopsy, an abundant fluid was detected in the abdominal cavity of all animals in both groups. Group 2 showed more adhesions than Group 1. No difference was found in microbial content of peritoneal fluid between the groups, and when compared the initial fluids with those founded by the end of the experiment.

In group 3, eight of the nine animals died within seven days after the second intraperitoneal stool injection, while the other rat remained alive throughout the 30 days of the follow-up. An increasing gain of weight was observed in these animals until the fourth month after intrabdominal injection of fecal solution ( $p$ $=0.032-$ ANOVA) (Table 1). There was no difference in survival time between the rats of group 3 and the control group (Group 1) $(\mathrm{p}=0.4738)$ (logrank test). It must be stressed that the survival time of the group 3 was considered after the second intrabdominal injection of fecal solution (higher amount), three months after the first injection (with lower amount of fecal solution). Numerically, the estimated hazard ratio for mortality in these two groups was 0.7465 (CI: $0.2131-2.051$ ). A large amount of pus was detected in all animals of this group at autopsy.

The difference in survival time between groups 2 and 3 was for $\mathrm{p}=0.0005$ (logrank test). The survival curves of the Groups 2 and $3(p=0.027)$ were discrepant. This comparison considered the survival time of the group 3 after the second injection of fecal solution. The estimated hazard ratio for mortality in these two groups was 12.89 (CI: 4.15 - 71.48) (Figure 1)

The difference in survival time between groups 1,2 and 
3 was for $\mathrm{p}=0.0042$ (logrank test). (Figure 1) Thus the animals of group 2 survived much more (30 days) than the rats of group 1 and of those included in group 3. As may be observed above, there was no difference between groups 1 and 3 .

\section{Discussion}

The present experiment showed that, when reinfection was induced after a short period of time, mortality was much lower than in the control group. This result indicates that the reduction in mortality after reinfection may be due, at least in part, to the immune defense acquired during the first infection. However, this protection is only temporary, since in the group studied after late reinfection mortality was exactly the same as in the control group. Two control groups were used to insure that the two fecal solutions used at different times were indeed lethal to the rats, whose age and weight were similar in the experiment groups and their respective controls.

The importance of IgM is recognized in the defense of the organism against bacterial infection in peritonitis, by inducing both local and systemic responses ${ }^{11}$. This opsonin promotes an increase in TNF- $\alpha$, IL-6 and neutrophil levels, in addition to activating the complement cascade, mainly $\mathrm{C} 3$. This mechanism possibly reduces the amount of peritoneal E. coli and serum LPS. The lack of specific IgM worsens all these parameters, increasing mortality ${ }^{12,13}$. Thus, it is probable that after one month the serum levels of IgM and of other immune factors were still elevated in group 2 animals, in contrast to group 3 animals, who did not show an adequate response to the new bacterial agression. However, it was not objective of the present investigation to test these hypotheses. In view of the results obtained, it is of pivotal importance to continue investigating this line of research in order to understand the defense mechanism induced by peritonitis, which protects the organism in the case of peritoneal reinfection. Even considering several hypotheses, we could not find data that may indicate the mechanisms resulting in the animals survival periods. Further studies must be proposed in order to evaluate these mechanisms.

The fact that late reinfection was followed by elevated mortality suggests that the acquired organic defense, that was effective in controlling peritonitis due to reinfection during an initial period, did not persist. This shows that the immune response to this infection probably does not depend on T lymphocytes, a fact that may explain this non-induction of immunological memory.

\section{Conclusions}

A milder peritoneal sepsis induced by a fecal solution elevates the organic resistance to a new, more intense, fecal contamination occuring after a short period of time. However, this defense does not persist over a prolonged period of time.

\section{References}

1. Gonnert FA, Recknagel P, Seidel M, Jbeily N, Dahlke K, Bockmeyer CL, Winning J, Lösche W, Claus RA, Bauer M. Characteristics of clinical sepsis reflected in a reliable and reproducible rodent sepsis model. J Surg Res. 2011;170:e123-34.

2. Chiang N, Fredman G, Bäckhed F, Oh SF, Vickery T, Schmidt BA, Serhan $\mathrm{CN}$. Infection regulates pro-resolving mediators that lower antibiotic requirements. Nature. 2012;484:524-8.

3. Bosshart H, Heinzelmann M. Targeting bacterial endotoxin: two sides of a coin. Ann N Y Acad Sci. 2007;1096:1-17.

4. Lugo JZ, Price S, Miller JE, Ben-David I, Merrill VJ, Mancuso P, Weinberg JB, Younger JG. Lipopolysaccharide O-antigen promotes persistent murine bacteremia. Shock. 2007;27:186-91.

5. Fieren MW. The local inflammatory responses to infection of the peritoneal cavity in humans: their regulation by cytokines, macrophages, and other leukocytes. Mediators Inflamm. 2012;2012:976241.

6. Moreno SE, Alves-Filho JC, Alfaya TM, da Silva JS, Ferreira SH, Liew FY. IL-12, but not IL-18, is critical to neutrophil activation and resistance to polymicrobial sepsis induced by cecal ligation and puncture. J Immunol. 2006;177:3218-24.

7. Brandão AM, Silva NG, Oliveira MV, Morais PH, Marques e Silva S, Sousa JB, Carneiro FP. Effects of abdominal sepsis in the healing of abdominal wall: experimental study in rats. Acta Cir Bras. 2011;26(Suppl 2):38-44.

8. Barrera G, Landoni V, Martire-Greco D, Chiarella P, Meiss R, Gómez SA, Alves-Rosa F, Rearte B, Isturiz M, Palermo MS, Fernández GC. Model of polymicrobial peritonitis that induces the proinflammatory and immunosuppressive phases of sepsis. Infect Immunol. 2011;79:1280-8.

9. Feterowski C, Weighardt H, Emmanuilidis K, Hartung t, Holzmann B. Immune protection against septic peritonitis in endotoxin-primed mice is related to reduced neutrophil apoptosis. Eur J Immunol. 2001;31:1268-77.

10. Zhou Y, Yang Y, Warr G, Bravo R. LPS downregulates the expression of chemokine receptor CCR2 in mice and abolishes macrophage infiltration in acute inflammation. J Leukoc Biol. 1999;65:265-9.

11. Moitra R, Beal DR, BelikoffBG, Remick DG. Presence of preexisting antibodies mediates survival in sepsis. Shock. 2012;37:56-62.

12. Knapp S, Matt U, Leitinger N, van der Poll T. Oxidized phospholipids inhibit phagocytosis and impair outcome in gram-negative sepsis in vivo. J Immunol. 2007;178:993-1001

\section{Correspondence:}

Prof. Luiz Ronaldo Alberti

Rua Professor Baroni, 151/401

30441-180 Belo Horizonte - MG Brazil

Tel.: (55-31)3504-1576

luizronaldoa@yahoo.com.br

Received: April 24, 2012

Review: June 21, 2012

Accepted: July 23, 2012

Conflict of interest: none

${ }^{1}$ Research performed at Laboratory of Experimental Surgery, Department of Surgery, Medicine School, Federal University of Minas Gerais (UFMG), Belo Horizonte-MG, Brazil. 